\title{
Just a suburban boy
}

Book Review

\section{LINDSAY BARRETT}

UNIVERSITY OF WESTERN SYDNEY

Craig McGregor

Australian Son: Inside Mark Latham

Pluto Press, North Melbourne, 2004

ISBN 1-86403-288-X

RRP \$24.95 (pb)

Margaret Simons

Quarterly Essay: Latham's World: The New Politics of the Outsiders Black Inc., Melbourne, 2004

ISBN 1-86395-197-0

RRP \$13.95 (pb)

Michael Duffy

Latham and Abbott

Random House Australia, Milson's Point, 2004 
ISBN 1-74051-318-5

RRP \$32.95 (pb)

Recently I spent some time in hospital. In the midst of one disturbed, dream-filled night I found myself in the back of a taxi. The driver was Paul Keating, and he was wearing a checked shirt. 'I'm only doing this, mate', he said (in the cadence we all know so well), 'driving this taxi, because I want to see what it's like.' It was the sombre, not the exuberant Keating-the dark prince-and he didn't smile once. I'd asked him to take me to the location of my childhood home, in inner Sydney, and while he had initially headed in the right direction, as we got closer he began to take an increasingly circuitous route, so that even as we appeared to be nearing the destination, at the same time we also seemed to be getting further and further away. And then I woke up, to the sound of moans and groans, clanging trolleys, and the dim dawn of another anxious day.

This dream, it seemed to me after thinking about it for a little while, was a perfect allegory for just what it is that we seem to want from our politicians: we want them to take us home. And quite often it seems, they get off to a promising start, appearing to head in exactly the direction we want to go. But sooner or later they always seem to get lost, and we're left once more with the realisation that we'll never actually get there, to that safe place where everyone is happy, where everything is under control, and there seems to be some sort of order to the world. There has probably never been an Australian politician who has understood this need on the part of the polity better than John Howard, a feature of Australian political history analysed in detail by Fiona Allon in an essay on Howard's deployment of rhetoric evoking memories of his childhood home in Earlwood in Sydney. ${ }^{1}$ True, no other Australian leader has ever been as effective as Howard in mobilising his own personal story as a political weapon, but quite a few have come close: Joe Lyons, Robert Menzies, Ben Chifley, Jim Cairns; it could easily become quite an extensive list, and of course, close to the top would be Mark Latham, the ultimate suburban boy.

As anyone who paid even the slightest attention to the ups and downs of Australian political life during 2004 knows, Latham's personal story, his rise from boyhood on struggle street to the opposition leader's office, was repeated again, and again, and again, and again; and not just by him either, but by all the reputation makers and shapers and wreckers who vie daily for column space and screen time and airwave frequencies. And then, as we all know, tragically, he was gone. Just like that. And make no bones about it, it really was a tragedy, both for Latham as a human being and for the theatre of our public life, which he was doing such a vital job of shaking up. What's more, his departure constituted an even bigger tragedy for us cultural theorists, due mainly to the fact that, in a public domain in which superficiality increasingly appears to know no bounds, he'll 
generally be remembered not as the man who made the observation that 'all politics is cultural now', but as the man who called John Howard an 'arse-licker'. ${ }^{2}$

For Australian politics, Latham was a bit like Foucault's 'dangerous individual'. ${ }^{3}$ He was dangerous, within Australian public life at least, because he was both a brute fighter and an intellectual: a rare combination that literally destabilised our politics. And plenty of the narrowers and the straighteners, as Manning Clark liked to call them, are happy to see him gone. He took the tactic of violent verbal abuse of the hated Liberals to new heights, and yet he also wrote thoughtful, intelligent and constructive books on a range of aspects of Australian social life, displaying an intellectual capacity that no member of the government could match. Perhaps then it is this affinity for the written word that in part explains why Mark Latham was the central subject of more books on Australian politics published during 2004 than anyone, or anything, else. Indeed, not since John Kerr's sacking of Latham's mentor (or tutor) Gough Whitlam has Australian political writing and publishing had such a shot in the arm as that provided by Latham's elevation to leadership of the Australian Labor Party in December 2003.

Who though, will want to read these books now? Pages and pages of opinions and ink devoted to the man who would be Australia's next prime minister, who subsequently left politics before you even got to read this review. In a sense though this disposability is quite appropriate, as these three publications are all basically extended pieces of journalism. This highlights a growing problem with the way in which politics is both performed and written about in Australia, but I'll get back to that in a minute.

As I said, these books are all pieces of journalism, which probably isn't surprising as they are all written by journalists. Craig McGregor has been interested in Latham for nearly a decade, and he wrote his first weekend supplement profile piece on him in 1997. Thus McGregor constructs much of his semilinear narrative around time spent with Latham: having lunch with him at Cabramatta in his electorate of Werriwa, driving around the part of south-west suburban Sydney where he grew up, waiting for him to appear at a town hall meeting at Tweed Heads on the New South Wales north coast, and so on. It's a personal portrait, and it interweaves reflections on Latham's policies and the state of Australian politics as McGregor sees it at the moment, with the by-now famous (infamous?) Latham story. While McGregor is interested in policy, it's the Latham saga that really propels the book, a 'classic case of someone who has dragged himself up, with some help, from an underprivileged background and now aspires to the highest office in the land'. (128) Telling this story entails, of course, repeating all the key moments of personal development, family crisis and alleged professional scandal that make up Latham the public man. And this is 
done without the slightest hesitation. Given that this is a public figure we're talking about, it all appears to be public property.

In her Quarterly Essay on Latham, Margaret Simons also utilises a first person narrative voice extensively. Unlike McGregor, however, she is much more interested in Latham's policies rather than his personality; primarily it would appear, because she couldn't actually get to talk to him. Latham's office, she assumes, perceived her to be some sort of latte-drinking wanker, writing merely for other latte-drinking wankers, and therefore not worth time and effort in the lead-up to an election. They were probably right, but nonetheless this is a very good analytical essay on the state of Australian politics in 2004, and on the historical and cultural background to Lathamism (if we can call it that), though I doubt whether the writer's point of view needs to be stressed as much as it is. This, however, is what the genre of 'quality political journalism' (as pioneered by, for example, Joan Didion) requires, and so this is what we get.

In contrast to Simons and McGregor, Michael Duffy keeps himself out of his account of the contrasting personal and political lives of Mark Latham and Tony Abbott, Latham and Abbott. This is a good thing, as the two of them are more than enough already, without adding a third overtly opinionated participant. Indeed, this appears at first a curious book, running these two very different lives in a parallel narrative construction, which could almost be seen as experimental modernism were it not for the utter flatness of Duffy's prose. As it goes on though, you come to see that Duffy is right, and that, as public men, as much as these two are different they are also, on one level, very much the same. The book even builds to a climax, as all good narratives should, with the pair finally meeting and politically consummating their relationship, slugging it out in parliament and insulting each other with an inventively vicious capacity that no one else in the house could come near. And now there's only one left, though this was no victory for Abbott. Quite the opposite, as Duffy's book depends crucially on Latham to make it work, since no one with as unpleasant a public persona as Tony Abbott could ever sustain a story like this on his own.

Duffy, more so even than McGregor, follows the personal in order to construct the political, and detail builds upon detail to the extent that we even find out that Mark Latham's favourite film is Apocalypse Now, while Abbott likes films starring John Wayne, in particular Red River. Such an observation has the potential to move you to tears in its poignantly ironic implications, but on another level it's indicative of the major problem at the heart of the media-politics nexus in contemporary Australia, indeed in the contemporary West in general. Increasingly, all that our politics is seen to be about is the individual's story. And it doesn't matter who is speaking, whether it is the politician or the journalist or the academic, it's personality not policy that matters. 
What sort of a hypocrite are you, you are probably asking? You started this review with a personal anecdote, and now you're complaining about the personalisation of political writing. And you're probably right, but when I sat down to write about these books, that's the approach that immediately seemed appropriate. Because that's the sort of approach that the contemporary political culture dictates, if you act first and think about it later, or even if you do think about it but want to make sure you really do get the consumer's attention. That's why these three books all deal, to a great extent, with Latham the personality. And that's why he provoked so much study and opinion regurgitation during 2004, because he was interesting in a tabloid kind of way, with his big mouth and his rude language and his disregard for etiquette, not because he wanted men to read to their children. And that's why so much of the trivial, superficial rubbish that passed as political journalism during the last election campaign focused on Latham's personal life rather than on Labor policy-a media climate that made it, of course, so much easier for the government's information management machine to paint him as some kind of lunatic who would make interest rates go through the roof just because he liked to wreck things.

Of course, modern politics has always been about the individual to some extent. After all, the whole point of democracy is representation. We select (theoretically anyway) someone to represent us, and they do this mainly through their rhetorical skills. But increasingly, this is all the political process is becoming, this construction and/or destruction of the personality of the political actor. This is a problem that is no in way confined to Australia either. Bill Clinton's primary legacy turned out to be Monica Lewinsky; Tony Blair was allowed to go to war against Iraq because he personally was convinced that Saddam had weapons of mass destruction tucked away; Viktor Yuschenko's demolished face appeared on every news magazine cover in the world, and so on. I don't need to point out which side this turn of events favours, but I will anyway. For a set of ideologies thatpreach triumphant individualism and self-centredness, this is a wonderful development.

Lindsay Barrett is a researcher at the Whitlam Institute, University of Western Sydney. $<$ la.barrett@uws.edu.au>

${ }^{1}$ Fiona Allon, 'Home as Cultural Translation: John Howard's Earlwood, Communal/Plural, no. 5, 1997, pp. 1-25.

${ }^{2}$ Mark Latham, From the Suburbs: Building a Nation from our Neighbourhoods, Pluto Press, Annandale, 2003. p. 19

${ }^{3}$ Michel Foucault, 'The Dangerous Individual', in Politics, Philosophy, Culture: Interviews and Other Writings 1977-1984, ed. Lawrence D Kritzman, trans. Alan Sheridan and others, New York, Routledge, 1988, pp. 125-151.
} 